\title{
Efficiency Evaluation of Rural E-commerce Supply Chain Management based on Analytical Hierarchy Process
}

\author{
Guangliang Zhou and Yawen Guo \\ Zhengzhou University of Light Industry, Zhengzhou 450002, China \\ zhouguangliang1969@163.com,827424591@qq.com
}

Keywords: Internet plus; Rural e-commerce; Supply chain; Analytic hierarchy process; Efficiency evaluation

\begin{abstract}
With the great "internet + " concept putting forward and widely used, life in cities are getting much more convenient. The city market can witness the intelligentialize lifestyle everywhere, while for the country, as the blank market, it becomes the competition areas. In the base of the e-supply chain ties closely the cities and the countryside, pushing forward of the economy and improving the living standard of the peasant. Through field investigation and literature analysis, established the index system from the five aspects of commodity circulation in the process of cost, convenience, social, quality, farmers profit level, by using analytic hierarchy process AHP on government support, product positioning, target information system technology. The three main influencing factors of rural e-commerce the efficiency of the supply chain management, the policy support of the government is to enhance the core management efficiency, application of information system. Technology is the basis to ensure the supply chain flow, accurate positioning of the target product can be better to promote product marketing.
\end{abstract}

\section{Introduction}

In recent years, with the rapid development of china's economy, people's living standards gradually improved. However, due to the construction of infrastructure has not kept pace with the pace of economic development, resulting in a large number of rural residents to buy fake and shoddy products. And also a large number of city residents "assured" agricultural products, led to the whole society especially the highly concern about food safety. With the popularity of Internet technology, as a new type of business model of rural e-commerce, for the construction of new rural and urban supply chain provides opportunities for the development. It reduces the cost of circulation, but also improves the efficiency of the distribution channels. To achieve the integration of urban and rural areas, and agricultural information is to make an important contribution. In order to let rural e-commerce play a greater role, we must solve the bottleneck factors restricting its development and to remove or improve, and to take targeted policy measures to promote the rapid development of rural e-commerce. The effects of various factors of rural e-commerce supply chain management efficiency based on the analysis, to establish the hierarchical structure model, the relationship between different factors obtained through field research; through model processing, to determine the importance of different factors, and the clustering analysis analyzes the influence degree of each factor on the rural e-commerce supply chain.

\section{Analysis on the Influencing Factors of the Management Efficiency of the Rural E-Commerce Supply Chain}

The influence factors of the management efficiency of the rural e-commerce supply chain are complex. The paper analyzes the three aspects of the government support, the target product positioning, and the information system technology based on its own characteristics ${ }^{[1]}$.

Government Support. With the advance of "Internet +" concept and promote the application of e-commerce in rural areas gradually by the local government policy in all aspects of Taxation, transportation and infrastructure support. At the same time, the local government for the 
corresponding link system to carry out the occupation training of rural e-commerce, and constantly improve the quality of farmers, so that farmers are fully aware of the necessity of e-commerce in the development of the rural economy and operability; mobilize the farmers to make full use of the "Internet +" E-commerce enthusiasm, expand the influence the scope of rural e-commerce. At the same time, the local government reasonable plans for rural e-commerce planning and investment, the actual demand for the construction of e-commerce in rural areas focus on the classification results based on the target of product market and the various regions, the rational allocation of e-commerce infrastructure investment ${ }^{[2]}$. Government incentives to actively use e-commerce in rural households, to actively participate in the training and subsidy policy incentives using "Internet + " e-commerce in rural households; encourage various occupation training institutions fully oriented farmers; improve the government supervision mechanism and credit evaluation mechanism, improve the rural e-commerce supply chain management efficiency.

Target Product Positioning. Have own unique product advantages of e-commerce in rural areas in different regions, need product information standards for rural unified reform, through the centralized collection of different areas of product information, determine the standard for rural electronic commerce. In the early stage, farmers are unfamiliar to the target product positioning and fuzzy, according to the regional characteristics and advantages, the use of special training before the farmers settled in e-commerce area, waiting for the operation to mature, according to the actual situation of its own accurate positioning of its target product and project. To implement the classification management of target products, and with a reasonable logistics mode, but also for the needs of farmers to set some special products. Play the role of e-commerce in rural areas in the supply chain to maximize the integration of urban and rural construction, can the rural two-way e-commerce market transaction mode, so as to expand the rural market on the original advantages of products, establish special channel other related advantages of products, green and sustainable development to promote regional e-commerce supply chain, accelerate the characteristic target product brand.

Information Systems Technology. The popularization and application of information system technology has brought convenience to people's life, but the popularization of information technology in rural areas has a gradually accepted and applied process. Rural e-commerce information technology platform to build a good platform for the client and service team, according to the project investigation and data collection statistics, site maintenance operations, customer information processing, information sharing and comprehensive coordination work to provide docking, can make up the defects of the lack of information asymmetry and transaction mode of the traditional rural area. Using information technology to carry out two-way supervision and tracing of the target products, mainly to monitor the whole process of production, processing and circulation of agricultural products, and guide the farmers to carry out scientific and rational production of agricultural products. At the same time, it can be traced back to a variety of products into the rural areas, to ensure the safety of farmers' consumption, to achieve the goal of increasing farmers' income and improving the quality of life[3].

\section{The Application of the Level Analysis Method in Evaluating the Efficiency of the Supply Chain Management of the Rural Electronic Commerce}

According to the main influencing factors of rural e-commerce supply chain management efficiency can be divided into: (1) the support of the government, a reasonable distribution of e-commerce infrastructure investment, resulting in increased profits; (2) the target product positioning, channel characteristics establish the advantages of the product, to avoid unnecessary loss of profit and loss; (3) information system, to avoid the defects and shortage of information asymmetry, to guide farmers to carry out scientific and reasonable production of agricultural products[4]. Based on these three influencing factors, we put forward the following five evaluation factors [5]: 
(1) Cost: cost refers to all the costs of transportation, warehousing, labor, trade and other costs arising from the daily circulation of agricultural products, agricultural means of production and daily necessities of life.

(2) Convenience: convenience is a measure of a variety of agricultural products, agricultural production materials and daily necessities of life in the daily circulation process, the degree of difficulty of the commodity circulation index.

(3) Social: society refers to a variety of agricultural products, agricultural production and daily necessities of life to the social benefits in the daily circulation process, including economic development, industrialization and modernization level etc..

(4) Quality: refers to the quality of various agricultural products, agricultural production and daily necessities of life to maintain the original quality goods the condition in the daily circulation process, the general circulation in the course of the loss of more, its quality is worse.

(5) The level of profitability: profitability refers to the peasant farmers in the whole process of commodity circulation of farmers through the sale of agricultural products and the income obtained by the difference between the purchase of agricultural production materials and daily necessities of life consumption costs, increasing income of farmers, spend less, the profit level is higher [6].

The Establishment of Level Structure Model. According to the relationship between the factors can be divided into three levels, the establishment of hierarchical structure model, as shown in Fig. 1.

Target layer A: Improve the efficiency of rural e-commerce supply chain management

Criteria layer B: Cost $\mathrm{B}_{1}$, Convenience $\mathrm{B}_{2}$, Social $\mathrm{B}_{3}$, Quality $\mathrm{B}_{4}$, The farmer's profit level $\mathrm{B}_{5}$

Program level $\mathrm{C}$ : Government support $\mathrm{C}_{1}$, Target product positioning $\mathrm{C}_{2}$, Information system technology $\mathrm{C}_{3}$

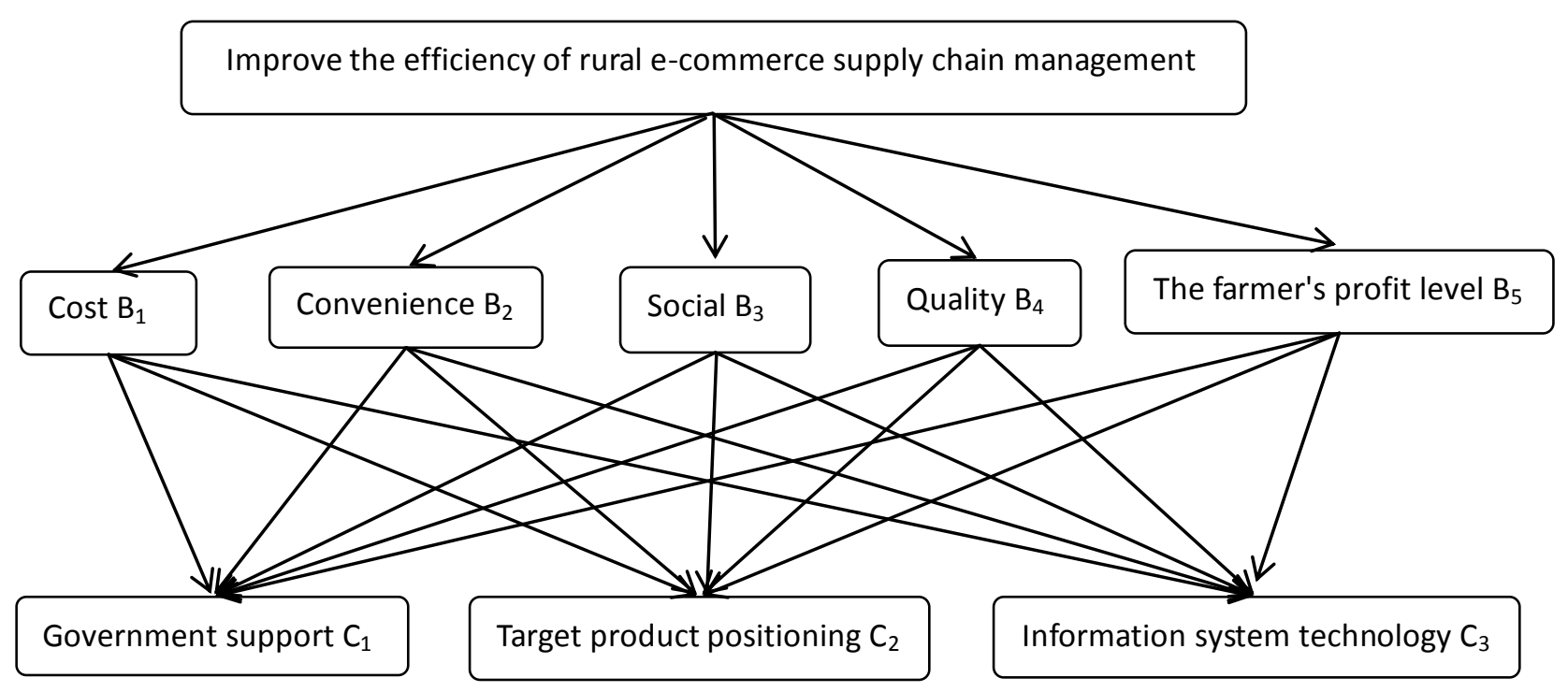

Figure 1. Rural e-commerce supply chain efficiency structure model

Structure Judgment Matrix. The main influencing factors of rural e-commerce supply chain management to improve the efficiency of respectively (1) government support, a reasonable distribution of e-commerce infrastructure investment, resulting in increased profits; (2) the target product positioning, channel characteristics establish the advantages of the product, to avoid unnecessary loss of profit and loss; (3) information system technology, to avoid the defects and shortage of information asymmetry, to guide farmers to carry out scientific and reasonable production of agricultural products. Therefore, to judge the importance of each evaluation factor is mainly based on the contribution of each evaluation factor to the above three factors. The degree of importance of hypothesis of three factors is the same, 6 staff with rich experience in the 
composition of the expert panel to set the index weights of each layer, the first group of experts will be divided into 3 groups, respectively determine different index weights; secondly according to the 22 index comparison principle and 1-9 scale method (Table 1) compared the assignment; finally the collective discussion and determination of weight of each group set[7]. After discussion, the relationship between the various indicators, and then according to the set of indicators of the expert group to determine the weight of the index, to construct a corresponding judgment matrix, as shown below:

Table 1 Evaluation scale

\begin{tabular}{|l|l|}
\hline Scale $\mathrm{A}_{\mathrm{ij}}$ & Definition \\
\hline 1 & $\mathrm{i}$ factors and $\mathrm{j}$ factors are of the same importance \\
\hline 3 & i factors and $\mathrm{j}$ factors are slightly important \\
\hline 5 & i factors and $\mathrm{j}$ factors are important \\
\hline 7 & i factors and $\mathrm{j}$ factors are significantly important \\
\hline 9 & i factors and $\mathrm{j}$ factors are absolutely important \\
\hline $2 、 4 、 6 、 8$ & between the two factors in the middle of the state \\
\hline Reciprocal & if the $\mathrm{j}$ factors and I factors, the judge value is $\mathrm{A}_{\mathrm{ij}}=\mathrm{A}_{\mathrm{ji}}$ \\
\hline
\end{tabular}

Table 2 Judgement matrix of each influence factor

\begin{tabular}{|c|c|c|c|c|c|}
\hline $\mathrm{A}$ & Cost $\mathrm{B}_{1}$ & Convenience $\mathrm{B}_{2}$ & Social $\mathrm{B}_{3}$ & Quality $\mathrm{B}_{4}$ & Farmers earnings $\mathrm{B}_{5}$ \\
\hline Cost $\mathrm{B}_{1}$ & 1 & $1 / 2$ & 5 & 4 & 3 \\
\hline Convenience $\mathrm{B}_{2}$ & 2 & 1 & 3 & 4 & 5 \\
\hline Social $\mathrm{B}_{3}$ & $1 / 5$ & $1 / 3$ & 1 & $1 / 3$ & $1 / 2$ \\
\hline Quality $\mathrm{B}_{4}$ & $1 / 4$ & $1 / 4$ & 3 & 1 & 1 \\
\hline Farmers earnings $\mathrm{B}_{5}$ & $1 / 3$ & $1 / 5$ & 2 & 1 & 1 \\
\hline
\end{tabular}

Table 3 Influencing factors B1--C judgment matrix

\begin{tabular}{|c|c|c|c|}
\hline $\mathrm{B}_{1}$ & $\begin{array}{c}\text { government support } \\
\mathrm{C}_{1}\end{array}$ & $\begin{array}{c}\text { target product } \\
\text { positioning } \mathrm{C}_{2}\end{array}$ & $\begin{array}{c}\text { information system } \\
\text { technology } \mathrm{C}_{3}\end{array}$ \\
\hline $\begin{array}{c}\text { government support } \\
\mathrm{C}_{1}\end{array}$ & 1 & 3 & 5 \\
\hline $\begin{array}{c}\text { target product } \\
\text { positioning } \mathrm{C}_{2}\end{array}$ & $1 / 3$ & 1 & 4 \\
\hline $\begin{array}{c}\text { information system } \\
\text { technology } \mathrm{C}_{3}\end{array}$ & $1 / 5$ & $1 / 4$ & 1 \\
\hline
\end{tabular}

Table 4 Influencing factors B2--C judgment matrix

\begin{tabular}{|c|c|c|c|}
\hline $\mathrm{B}_{2}$ & $\begin{array}{c}\text { Government support } \\
\mathrm{C}_{1}\end{array}$ & $\begin{array}{c}\text { Target product } \\
\text { positioning } \mathrm{C}_{2}\end{array}$ & $\begin{array}{c}\text { Information system } \\
\text { technology } \mathrm{C}_{3}\end{array}$ \\
\hline $\begin{array}{c}\text { Government support } \\
\mathrm{C}_{1}\end{array}$ & 1 & $1 / 5$ & $1 / 7$ \\
\hline $\begin{array}{c}\text { Target product } \\
\text { positioning } \mathrm{C}_{2}\end{array}$ & 5 & 1 & $1 / 3$ \\
\hline $\begin{array}{c}\text { Information system } \\
\text { technology } \mathrm{C}_{3}\end{array}$ & 7 & 3 & 1 \\
\hline
\end{tabular}


Table 5 Influencing factors B3--C judgment matrix

\begin{tabular}{|c|c|c|c|}
\hline $\mathrm{B}_{3}$ & $\begin{array}{c}\text { Government support } \\
\mathrm{C}_{1}\end{array}$ & $\begin{array}{c}\text { Target product } \\
\text { positioning } \mathrm{C}_{2}\end{array}$ & $\begin{array}{c}\text { Information system } \\
\text { technology } \mathrm{C}_{3}\end{array}$ \\
\hline $\begin{array}{c}\text { Government support } \\
\mathrm{C}_{1}\end{array}$ & 1 & 1 & 5 \\
\hline $\begin{array}{c}\text { Target product } \\
\text { positioning } \mathrm{C}_{2}\end{array}$ & 1 & 1 & 3 \\
\hline $\begin{array}{c}\text { Information system } \\
\text { technology } \mathrm{C}_{3}\end{array}$ & $1 / 5$ & $1 / 3$ & 1 \\
\hline
\end{tabular}

Table 6 Influencing factors B4--C judgment matrix

\begin{tabular}{|c|c|c|c|}
\hline $\mathrm{B}_{4}$ & $\begin{array}{c}\text { Government support } \\
\mathrm{C}_{1}\end{array}$ & $\begin{array}{c}\text { Target product } \\
\text { positioning } \mathrm{C}_{2}\end{array}$ & $\begin{array}{c}\text { Information system } \\
\text { technology } \mathrm{C}_{3}\end{array}$ \\
\hline $\begin{array}{c}\text { Government support } \\
\mathrm{C}_{1}\end{array}$ & 1 & 2 & 3 \\
\hline $\begin{array}{c}\text { Target product } \\
\text { positioning } \mathrm{C}_{2}\end{array}$ & $1 / 2$ & 1 & 1 \\
\hline $\begin{array}{c}\text { Information system } \\
\text { technology } \mathrm{C}_{3}\end{array}$ & $1 / 3$ & 1 & 1 \\
\hline
\end{tabular}

Table 7 Influencing factors B5--C judgment matrix

\begin{tabular}{|c|c|c|c|}
\hline $\mathrm{B}_{5}$ & $\begin{array}{c}\text { Government support } \\
\mathrm{C}_{1}\end{array}$ & $\begin{array}{c}\text { Target product } \\
\text { positioning } \mathrm{C}_{2}\end{array}$ & $\begin{array}{c}\text { Information system } \\
\text { technology } \mathrm{C}_{3}\end{array}$ \\
\hline $\begin{array}{c}\text { Government support } \\
\mathrm{C}_{1}\end{array}$ & 1 & 2 & 5 \\
\hline $\begin{array}{c}\text { Target product } \\
\text { positioning } \mathrm{C}_{2}\end{array}$ & $1 / 2$ & 1 & 3 \\
\hline $\begin{array}{c}\text { Information system } \\
\text { technology } \mathrm{C}_{3}\end{array}$ & $1 / 5$ & $1 / 3$ & 1 \\
\hline
\end{tabular}

Calculate the Weight Vector and the Consistency Check of the Hierarchical Order Form.

Based on the judgment matrix $\mathrm{A}$ and calculation formula $\lambda_{\max }=\sum_{i=1}^{n} \frac{(A \omega)_{i}}{n \omega_{i}}$ can be derived by maximum characteristic matrix A value $\lambda_{\max }=5.2692$; the corresponding normalized feature vector $\omega=\{0.3026,0.4088,0.0700,0.1164,0.1021\} ; \mathrm{CI}=0.0673$, the corresponding $\mathrm{RI}=1.12$; therefore, $\mathrm{CR}=0.0601<0.1$ showed that the A matrix has been tested by the consistency check [8].

At the same time, the B1, B2, B3, B4, B5 to carry out the weight of the rank of the weight vector calculation, and the consistency test, the results obtained as shown in table $8, \mathrm{~B}_{1}, \mathrm{~B}_{2}, \mathrm{~B}_{3}, \mathrm{~B}_{4}, \mathrm{~B}_{5}$ are through the consistency test.

Table 8 Weight vector calculation of hierarchical total ranking

\begin{tabular}{|c|c|c|c|c|c|}
\hline $\mathrm{k}$ & 1 & 2 & 3 & 4 & 5 \\
\hline$\omega_{\mathrm{k} 1}$ & 0.6193 & 0.0738 & 0.4796 & 0.5485 & 0.5813 \\
\hline$\omega_{\mathrm{k} 2}$ & 0.2842 & 0.2828 & 0.4055 & 0.2409 & 0.3092 \\
\hline$\omega_{\mathrm{k} 3}$ & 0.0961 & 0.6434 & 0.1150 & 0.2106 & 0.1096 \\
\hline$\lambda_{\mathrm{k}}$ & 3.0858 & 3.0649 & 3.0291 & 3.0183 & 3.0037 \\
\hline $\mathrm{CI}_{\mathrm{k}}$ & 0.0429 & 0.0325 & 0.0146 & 0.0092 & 0.0019 \\
\hline $\mathrm{RI}_{\mathrm{k}}$ & 0.58 & 0.58 & 0.58 & 0.58 & 0.58 \\
\hline $\mathrm{CR}_{\mathrm{k}}$ & 0.0740 & 0.0559 & 0.0251 & 0.0158 & 0.0032 \\
\hline
\end{tabular}


Calculation of the Total Order Weight and Consistency Check. From the above calculation can launch $\mathrm{C}_{1}$ on the overall goal of $\mathrm{A}$ weight: $0.6193 * 0.3026+0.0738 * 0.4088+0.4796 * 0.0700+0.5485 * 0.1164+0.5813 * 0.1021=0.3743$; also can calculate $\mathrm{C}_{2}$ and $\mathrm{C}_{3}$ of the total target weights were: $0.2896,0.3359$. Therefore, the weight vector of the decision-making level to the general target is: $\{0.3743,0.2896,0.3359\}$.

At the same time, also can calculate the random consistency ratio $C R$ value is: $0.0429 * 0.3026+0.0325 * 0.4088+0.0146 * 0.0700+0.0092 * 0.1164+0.0019 * 0.1021=0.0286<0.1$, so it can be concluded that the level of total order through the consistency test, $\{0.3743,0.2896,0.3359\}$ can be used as the final decision according to the.

\section{Results Analysis}

According to the above results, the weight of the key indicators of the efficiency of the supply chain management in the rural e-commerce can be analyzed as follows:

(1) The government support in the rural e-commerce supply chain management efficiency of the weight of $37.43 \%$. The management of government agencies to improve rural e-commerce supply chain, improve the management mechanism, establish reasonable and effective rules and regulations, perfecting the credit evaluation system, can effectively solve the problem of distribution of interests of each node in the supply chain of e-commerce in rural areas, improve stakeholders participation enthusiasm, also can strengthen the effective supervision of the public opinion environment. The government should make policy guidance and effective project information era the development of strong promotion, such as involving the public welfare platform can be open for free and use of farmers, in order to maximize the potential for the development of the entire chain, improve the rural e-commerce supply chain management efficiency.

(2) The information system technology in the rural e-commerce supply chain management efficiency of the weight of $33.59 \%$. The information system technology mainly through standard database system, digital port information data sharing and other aspects of establishing unified and mature information transmission channels, the supply chain transfer and sharing of high quality information. Integrated management of the entire supply chain, the development of multi region and multi suppliers and supply channels, with full tracking of every supplier, every customer, every piece of merchandise, the node upstream and downstream suppliers, customers and other supply chain e-commerce platform has a high degree of integration. The abnormal phenomenon in a timely and efficient manner to make decisions, to avoid unnecessary losses, so as to improve profits, enhance management efficiency and enhance the stability and security to the full realization of rural e-commerce supply chain management, information visualization.

(3) The target product positioning in the rural e-commerce supply chain management efficiency of the weight accounted for $28.96 \%$. Reasonable positioning of target product can make each region according to its own characteristics to gain a foothold in the supply chain of electronic commerce in the rural areas, and actively develop new products with the characteristics, application of new technology, timely replacement, effectively improve the production process, more efficient to adapt the rapid development trend; at the same time according to the service function part the potential development of individual farmers, the farmers' consumption demand and profit potential release to the relevant ideas[9].

In the platform, according to the information system to collect and count the details, so as to carry out selective development, reasonably balanced investment, and gradually form a virtuous cycle of product and project development of the target market.

\section{Conclusion}

From the research results of this paper, the three criteria layers of government support in the entire rural e-commerce supply chain is the most important, followed by the information system technology and target product positioning. Combined with the practice of rural e-commerce supply chain management efficiency, government policy support is the core of government information 
infrastructure, e-commerce platform, technical staff, product supply and demand and other resources, reasonable regulation and guidance, make effective arrangements; constantly improve various laws and regulations related to rural e-commerce the establishment of effective supervision and management mechanism; strengthen the construction of transportation and communication network and a series of public infrastructure; introduce, encourage and train all kinds of talents engaged in rural electronic commerce. The application of information system technology is the foundation of supply chain, supply and demand, to construct the model through the two-way rural e-commerce transaction mode, promote agricultural products and agricultural products need to fast circulation; effective management of rural e-commerce supply chain; traceability of the implementation of the supply chain to ensure various target products, agricultural products and agricultural goods required the high quality of circulation[10]. The accurate positioning of the target products, features and standardization of the product is more suitable for network marketing; the scientific positioning of the target products and standardized classification process can better promote the marketing of the target product. Continuous optimization of the above three levels, can fully improve the management efficiency of the rural e-commerce supply chain, fully adapt to the development of China's rural e-commerce.

\section{References}

[1] C.G. Li, Commercial economic analysis of rural e-commerce model "Internet +" [J], Commercial economy research, 2015 (In Chinese).

[2] Q.Y. Wang, H.M. Qian, Based on analysis of business model characterized by the integration of online channel[J], Commercial economy research,2015 (In Chinese).

[3] H.Q. Zhou, C.M. Zhang, China's rural electronic commerce key element analysis [J], China's information industry, 2012 (In Chinese).

[4] Akan M AtaB, Lariviere M.A, Asymmetric information and economies-of-scale in service contracting, Manufacturing and service operactions managemengt, 2011 (In Chinese).

[5] Y.J. Wu, Study on the optimization of rural circulation supply chain under the e-commerce environment [D], Chengdu University of Technology, 2014 (In Chinese).

[6] Z.G. Yang, The circulation of agricultural products and farmers' income problem research [J], Modern circulation, 2013 (In Chinese).

[7] Z.D. Shen, Construction of the performance evaluation system of state owned enterprises by using analytic hierarchy process [J], Audit research, 2013 (In Chinese).

[8] X. Deng, J.M. Li and H.J. Zeng, et al, Analysis and application of analytic hierarchy process weight calculation method and its application research $[\mathrm{J}]$, mathematics practice and understanding, 2012 (In Chinese).

[9] H.P. Li, The problems existing in the electronic commerce and model innovation [J], Journal of Shaanxi University of Science and Technology, 2011 (In Chinese).

[10] Y.J. Wu, J.L. Yan, Based on the electronic commerce environment logistics model research [J], Logistics engineering and management, 2013 (In Chinese). 